\title{
Simulating the impact of climate change on chickpea yield under rainfed and irrigated conditions in Madhya Pradesh
}

\author{
A.K.SRIVASTAVA*, SANDIPSILAWAT ${ }^{1}$ and K.K.AGRAWAL ${ }^{1}$ \\ College of Agriculture, JNKVV, Tikamgarh (M.P.)-472001 \\ ${ }^{1}$ College of Agriculture, JNKVV,Jabalpur(M.P.)-482004 \\ *Email: ajay_weather@yahoo.com
}

\begin{abstract}
CROPGRO-chickpea model calibrated and validated with data collected from the experiments conducted with two cultivars (JG 315 and JG 11) of chickpea at Jabalpur (irrigated) and Tikamgarh (rainfed) during 2009-10 and 2010-11, was used to study the impact of climate change on phenology, growth and yield of chickpea. It was found that model closely simulated the phenological event as well as biomass. The model underestimated seed yield of both the cultivars but more error was involved in simulation of JG 11. Under rainfed conditions there was large differences between observed and simulated. Under climate change scenarios (increasing maximum temperature by +1 to $+3{ }^{\circ} \mathrm{C}$, minimum temperature by +0.5 to $2.5^{\circ} \mathrm{C}$ and $\mathrm{CO}_{2}$ from 400 to $600 \mathrm{ppm}$ ); the seed yield of the chickpea cultivars would increased by 102.8 and 187.7 per cent under irrigated conditions at Jabalpur. The large variability in yield was noted under rainfed as compared to irrigated conditions.
\end{abstract}

Key words: Calibration, validation, simulation, CHIKPGRO model, climate change, phenology, yield,.

Climate change is one of the most important global issue all over the world and much more attentions have been paid to evaluate or eliminate its detrimental effects. To evaluate the effects of climate change, different crop models and scenarios have been developed and used across the world. The Decision Support System for Agro-technology Transfer (DSSAT) has been found to be most widely used decision support system which included models for cereals, legumes, oilseed, vegetable crops (Hoogenboom, 2000). Though different workers have evaluated the CROPGRO model for other crops viz. Pandey et al. (2001), Suriharan et al. (2008) and Patel et al. (2013) validated the CROPGRO model for groundnut. Bhatia et al. (2008) for soybean (Glycine max L. Merr.).

Chickpea occupy a very significant place in farming all over India and have the growing area of 9.91 million hectares with an annual production of 8.22 million tones and average productivity is $895 \mathrm{~kg} \mathrm{ha}^{-1}$ (Anonymous 2012). Madhya Pradesh share 33 per cent of total chickpea area and 38 per cent of total production (Anonymous, 2014).

To estimate the impact of climate change on predominate chickpea cultivars of Madhya Pradesh, five climate change scenario (taking business as usual scenario approach) was simulated and their impact on yield were analyzed.

\section{MATERIALS AND METHODS}

The input data required for running the crop simulation model(CROPGRO-Chickpea) of DSSAT V4.5 includes crop data, daily weather data, soil data and crop specific genetic coefficients.

\section{Crop data}

To evaluate the model, field experiments were conducted at Jabalpur (Lat. $23^{\circ} 09^{\prime} \mathrm{N}$ and Long. $79^{\circ} 58^{\prime} \mathrm{E}$. and altitude of $411 \mathrm{~m}$ m.s.l.) with six dates of sowing ( $D_{1}$ : October $11, \mathrm{D}_{2}$ :October 26, $\mathrm{D}_{3}$ : November11, $\mathrm{D}_{4}$ :November26, $\mathrm{D}_{5}$ :December 11, $\mathrm{D}_{6}$ : December 26) and two varieties (JG 315 and JG 11) during rabi seasons of 2009-10 and 2010-11. Two irrigation (40mm); one at branching and one at pod filling stages in addition to the pre-sowing irrigation were applied. The same cultivars under rainfed conditions were grown at Tikamgarh(Lat. $24^{\circ} 40^{\prime} \mathrm{N}$., Long. $77^{\circ} 80^{\prime} \mathrm{E}$. and altitude $324 \mathrm{~m}$ m.s.1.). during rabi 2009 10 and 2010-11. Sowing of the above two varieties of chickpea was done on $10^{\text {th }}, 17^{\text {th }}$ November in $2009,30^{\text {th }}$ October and $4^{\text {th }}$ November in 2010. A recommended dose of fertilizer 20-60-20 $\mathrm{kg} \mathrm{ha}^{-1}$ NPK was applied uniformly at the time of sowing. One pre-sowing irrigation was applied in the crop at Tikamgarh.

\section{Weather data}

The daily weather data of the year from 2009 to 2011 
Table 1: Climate change scenario selected for the study

\begin{tabular}{lccc}
\hline Climate change scenarios & Maximum temperature $\left({ }^{\circ} \mathrm{C}\right)$ & Minimum temperature $\left({ }^{\circ} \mathrm{C}\right)$ & $\mathrm{CO}_{2} \mathrm{concentration}(\mathrm{ppm})$ \\
\hline S1 & +1.0 & +0.5 & 400 \\
S2 & +1.5 & +1.0 & 400 \\
S3 & +2.0 & +1.5 & 450 \\
S4 & +2.5 & +2.0 & 500 \\
S5 & +3.0 & +2.5 & 600 \\
\hline
\end{tabular}

Table 2: Genetic coefficients chickpea cultivars JG 315 and JG 11

\begin{tabular}{|c|c|c|c|}
\hline $\begin{array}{l}\text { Genetic } \\
\text { Parameter }\end{array}$ & Description & JG 315 & JG 11 \\
\hline $\mathrm{CSDL}$ & $\begin{array}{l}\text { Critical Short Day Length below which reproductive development progresses } \\
\text { with no daylength effect (for short day plants) (hour) }\end{array}$ & 11.30 & 10.10 \\
\hline PPSEN & $\begin{array}{l}\text { Slope of the relative response of development to photoperiod with time } \\
\text { (positive for short day plants) ( } 1 \text { /hour) }\end{array}$ & -.143 & -.143 \\
\hline FL-SH & Time between first flower and first pod (R3) (photothermal days) & 8.0 & 8.0 \\
\hline FL-SD & Time between first flower and first seed (R5) (photothermal days) & 14.9 & 14.8 \\
\hline SD-PM & Time between first seed (R5) and physiological maturity (R7) (photothermal days) & 39.0 & 44.0 \\
\hline FL-LF & Time between first flower (R1) and end of leaf expansion (photothermal days) & 34.0 & 34.0 \\
\hline SIZLF & Maximum size of full leaf (three leaflets) $\left(\mathrm{cm}^{2}\right)$ & 8.90 & 9.2 \\
\hline XFRT & Maximum fraction of daily growth that is partitioned to seed + shell & 1.0 & 1.0 \\
\hline WTPSD & Maximum weight per seed (g) & 0.210 & 0.183 \\
\hline SFDUR & $\begin{array}{l}\text { Seed filling duration for pod cohort at standard growth conditions } \\
\text { (photothermal days) }\end{array}$ & 26.0 & 20.0 \\
\hline SDPDV & Average seed per pod under standard growing conditions (\#[seed]/pod) & 1.60 & 1.40 \\
\hline PODUR & $\begin{array}{l}\text { Time required for cultivar to reach final pod load under optimal conditions } \\
\text { (photothermal days). }\end{array}$ & 18.0 & 10.0 \\
\hline
\end{tabular}

were collected from Agromet Observatory situated nearby (within 100 meter) the experimental plots.

\section{Soil data}

Physical and chemical parameters of soil are required. The soil albedo, soil water drainage constant, filed capacity, wilting point, layer wise information on initial soil moisture, organic carbon, $\mathrm{pH}$ and sand, silt and clay information were collected from Jabalpur and Tikamgarh.

\section{Climate change Scenarios}

The climate change scenario were selected as per fifth assessment report of IPCC (2013), in which increase in maximum surface air temperature by $3.0^{\circ} \mathrm{C}$ and minimum air temperature by $2.5^{\circ} \mathrm{C}$ with combination of $\mathrm{CO}_{2}$ increase upto $600 \mathrm{ppm}$ have been projected. These are given in Table 1. The climate change was incorporated in the model input files through modified weather and then yield were simulated under five climate change scenarios under irrigated and rainfed conditions.

Test summary statistics like mean and standard deviation were also calculated. RMSE tests the accuracy of the model (Loague and Green, 1991) and set of RMSE values were calculated. A smaller RMSE indicated less deviation of the simulated from the observed values. The Coefficient of 


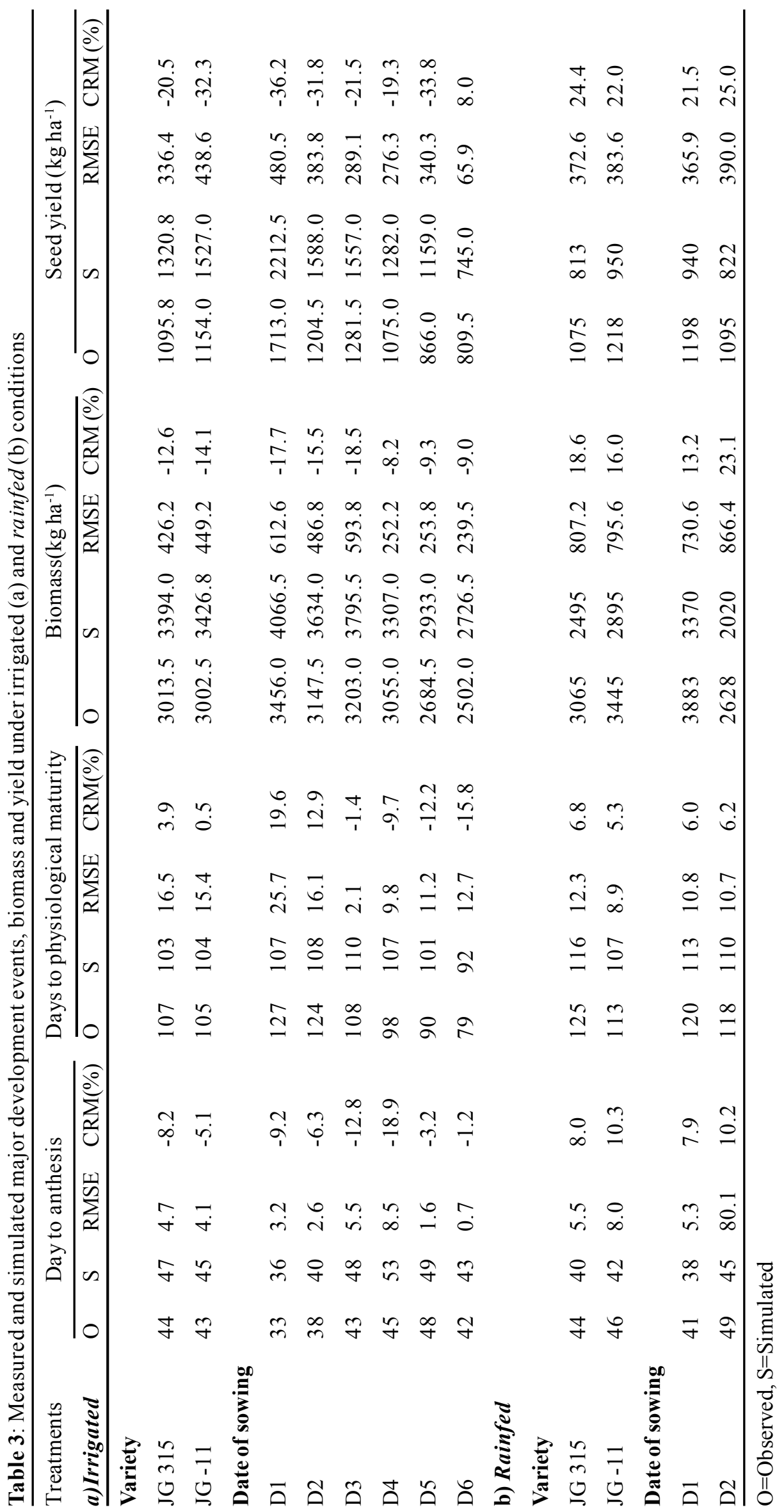


Table 4: Percentage change in yield under different climate change scenarios in irrigated and rainfed

\begin{tabular}{|c|c|c|c|c|c|}
\hline Treatments & S1 & S2 & S3 & S4 & S5 \\
\hline \multicolumn{6}{|l|}{ a)Irrigated } \\
\hline \multicolumn{6}{|l|}{ Variety } \\
\hline JG-315 & +102.8 & +110.9 & +121.3 & +129.4 & +137.5 \\
\hline $\mathrm{JG}-11$ & +138.5 & +150.6 & +165.9 & +172.1 & +187.6 \\
\hline \multicolumn{6}{|c|}{ Date of sowing } \\
\hline D1 & +208.6 & +217.9 & +231.5 & +242.0 & +256.6 \\
\hline D2 & +158.4 & +184.7 & +217.0 & +240.9 & +265.3 \\
\hline D3 & +160.0 & +165.4 & +173.7 & +184.8 & +200.7 \\
\hline D4 & +83.2 & +105.7 & +118.3 & +127.1 & +137.7 \\
\hline D5 & +91.6 & +100.1 & +119.5 & +116.6 & +129.2 \\
\hline D6 & +22.0 & +10.6 & +1.6 & -7.1 & -14.1 \\
\hline \multicolumn{6}{|l|}{ b) Rainfed } \\
\hline \multicolumn{6}{|l|}{ Variety } \\
\hline JG 315 & +61.8 & +66.6 & +73.2 & +77.2 & +96.7 \\
\hline JG -11 & +87.3 & +91.6 & 97.2 & +100.6 & +108.3 \\
\hline \multicolumn{6}{|c|}{ Date of sowing } \\
\hline D1 & +177.1 & +183.5 & +195.0 & +204.1 & +215.45 \\
\hline D2 & +127.5 & +143.5 & +165.5 & +183.2 & +205.20 \\
\hline D3 & +57.6 & +60.8 & +64.3 & +70.8 & +80.50 \\
\hline D4 & +52.0 & +59.2 & +60.3 & +62.5 & +65.45 \\
\hline D5 & +34.4 & +35.7 & +39.8 & +33.8 & +35.10 \\
\hline D6 & -1.5 & -8.1 & -13.7 & -21.2 & -13.40 \\
\hline
\end{tabular}

residual mass (CRM) was used to measure the tendency of the model to over estimate or under estimate the measured values. The CRM is defined by

$$
\mathrm{CRM}=100 \times\left[\mathrm{SO}_{\mathrm{i}}-\mathrm{SS}_{\mathrm{i}}\right] / \mathrm{SO}_{\mathrm{i}}
$$

Where, $\mathrm{O}=$ observed variable, $\mathrm{S}=$ simulated variable

A negative CRM indicates a tendency of the model towards over estimation (Xevi et al., 1996).

\section{RESULTS AND DISCUSSION}

\section{Calibration and Validation of CROPGRO mode}

The genetic coefficients for chickpea cultivars JG 315 and JG 11 were adopted from Silawat et al.(2016) and are given in Table 2. The model performance was assessed by running the model with independent crop data set for all six sowing days and two varieties at both the places Tikamgarh (rainfed) and Jabalpur (irrigated). The corresponding mean values of simulation results are reported in Table 2 and compared with experimental data and agreement has been checked by RMSE and CRM values.

Irrigated conditions (Jabalpur) : Table 3 shows that the model overestimated the anthesis days by 1 to 8 days across the variety and locations. The model underestimated the physiological maturity by 1 to 20 days across the different dates of sowing. The maximum difference was found for D1 sowing date. Except the early sown crop, the model showed the robustness in simulation of major phenological events.

Rainfed conditions (Tikamgarh) : At Tikamgarh, under irrigated conditions, the model underestimated the anthesis days with CRM ranging between 8 and 10 per cent and also the physiological maturity with CRM of 5 to 6 per cent (Table 3). The deviations between the simulated and observed biomass values were high for rainfed conditions.

The model performance for yield simulation for both the cultivars under rainfed condition was not within the acceptable limit $( \pm 20 \%)$. The model overestimated both the 
biomass and yield under irrigated conditions and under estimated the biomass and yield under rainfed conditions. These results indicated that modification may be incorporated in the model for acceptable yield simulation results. The crop models were generally calibrated for nonlimiting water conditions. In addition, other changes could also be made to accurately predict the observed water stress.

\section{Impact of climate change on seed yield}

The per cent change in seed yields of chickpea cultivars simulated under all the five climate change scenarios are presented in Table 4. It may be seen that the seed yield of chickpea was found to increase under all climate change scenarios. The yield increased with increase in $\mathrm{CO}_{2}$ concentration as well as with temperature.

Irrigated condition : Under irrigated conditions at Jabalpur the impact on seed yield of two cultivars varied between 102 and 187 per cent. Between the cultivars JG-11 was found to have more beneficial effect ( 138 to $187 \%$ ) than that of cultivar JG-315(102 to 137\%). The increase in $\mathrm{CO}_{2}$ concentration and maximum and minimum temperature had a profound influence on yield at different date of sowing and variety. In general the increase in $\mathrm{CO}_{2}$ concentration and maximum and minimum temperature has increased the seed yield. Srivastava (2003), also reported a high impact (40-50 per cent increase in yield) with doubling of $\mathrm{CO}_{2}$ concentration on the productivity of chickpea at Raipur. Vanaja et al. (2011) reported that seed yield of pigeonpea improved from $22.8 \mathrm{~g}^{-1}$ plant at ambient to $42.4 \mathrm{~g}^{-1}$ plant at $700 \mathrm{ppm}$, thereby showing an increment of 85.9 per cent with enhanced $\mathrm{CO}_{2}$.

Under irrigation conditions among the different dates of sowings, the impact was found to be beneficial in all except in extremely late sown condition (Dec.26). The highest seed yield increase ( +200 to $256 \%$ ) was obtained under D1 . With delay in sowing the impact of climate change was found to decrease. Under very late sown condition( D6), the impact of climate change under S1, S2 and S3 scenarios was positive while under $\mathrm{S} 4$ and $\mathrm{S} 5$ scenarios it was negative. Thus under irrigated conditions the beneficial effect of climate change was observed (Table 4). This result indicated that for maximization of chickpea yield the early sowing date is recommended under climate change conditions also.

Rainfed condition : The chickpea yield simulated under projected climate change scenarios (Table 4) showed beneficial effect in most of the cases under rainfed condition also. In this case variety, JG-11 was found to have more (87 to $108 \%$ ) beneficial effect than variety JG-315(61 to $97 \%$ ).
Under different dates of sowing the impact on seed yield was similar to that observed under irrigated conditions. However, quantitatively, it was slightly lower. The maximum beneficial effect was observed under early sown (D1- Oct-11) crop. Under very late condition (D6) the impact on seed yield was negative.

Seed yield variability was found to be large increased in case of climate change and large variability was noted under rainfed condition as compared to irrigated condition. Hajarpoor et al. (2014) simulated the impact of changing climate on chickpea at four major producing dry areas of Iran with different sowing dates. They reported that chickpea yield would increase between 37-89 per cent in rainfed conditions under the future climate in all sites.

\section{CONCLUSION}

The impact of climate change on chickpea yield was found to be favourable. The cultivar JG-11 would be more benefited than JG-315. The early sown (Oct.) crop would be maximum benefited. With delay in sowing, the beneficial effect will decrease. Under irrigated conditions the yield increase would be more that that under rainfed conditions. However, such results need to be used cautiously as the model has its inherent error in simulation.

\section{REFERENCES}

Anonymous, (2012). Agricultural Statistics at a Glance. Directorate of Economics and Statistics, Department of Agriculture and Co-operation, Govt. of India, pp: 8586.

Anonymous, (2014). Agro economic research for Madhya Pradesh \& Chhattisgarh JNKVV, Jabalpur Research study No.10 Annual Report, pp: 41-43.

Bhatia, V.S., Singh, P., Wani, S.P., Chauhan, G.S., Rao Kesava, A.V.R., Mishra, A.K. and Srinivas, K. (2008). Analysis of potential yields and yield gaps of rainfed soybean in India using CROPGRO-Soybean model. Agric. Forest Met., 148: 1252-1265.

Hajarpoor Amir, Soltani Afshin, Zeinali Ebrahim and Sayyedi Faramarz (2014). Simulating climate change impacts on production of chickpea under water-limited conditions. Agric. Sci.Dev., 3(6.): 209-217.

Hoogenboom, G. (2000). Contribution of agrometeorology to the simulation of crop production and its application. Agric. Forest Met. 103: 137-157. 
IPCC, (2013): Summary for Policymakers. In: Climate Change (2013). The Physical Science Basis. Contribution of Working Group I to the Fifth Assessment Report of the Intergovernmental Panel on Climate Change [Stocker, T.F., D. Qin, G.-K. Plattner, M. Tignor, S.K. Allen, J. Boschung, A. Nauels, Y. Xia, V. Bex and P.M. Midgley (eds.)]. Cambridge University Press, Cambridge, United Kingdom and New York, NY, USA.

Loague, K.M. and Green, R.E. (1991). Statistical and graphical methods for evaluating solute transport model. $J$. Contaminated Hyd., 7: 51-73.

Pandey, V., Shekh, A.M., Vadodaria, R.P. and Bhat, B.K., (2001). Evaluation of CROPGRO-Peanut model for two genotypes under different environments, Paper presented at the National seminar on Agro Meteorological Research for Sustainable Agricultural Production at GAU, Anand.

Patel, H.R.Lunagaria, M.M., Karade, B.L., Pandey, Vyas, Yadav, S.B., Shah,A.V.,Rao, V.U.M.andNaresh Kumar, S. (2013). Impact of projected climate change on groundnut in Gujrat. J Agromet. (Special issue),:81-84.
Silawat S.,A.K. Srivastava and K.K.Agrawal(2016).Evaluation ofCHIKPGRO model in semiarid and sub-humid climatic conditions of Madhya Pradesh. Mausam 67 (3) (in press)

Srivastava, A.K. (2003). Validation and Application of CROPGRO Model for crop management and yield prediction in chickpea crop, grown under agroclimatic conditions of north and central India. Ph.D. thesis (Unpublished), Dept. of Geophysics, B.H.U., Varanasi, pp1-151.

Suriharan, B., Patanothai, A., Pannagpetch, K., Jogloy, S. and Hoogenboom, G., (2008). Determination of cultivar coefficients of peanut lines for BreedingApplications of the CROPGRO-Peanut model. Crop Sci., 47: 606-620.

Vanaja, M.P., Reddy, R.R., Lakshmi, N.J., Yadav, S.K., Reddy, A.N., Maheswari, M. and Venkateswarlu, B. (2011). Yield and harvest index of short and long duration grain legume crops under twice the ambient $\mathrm{CO}_{2}$ levels. Indian J. Agric. Sci., 81(7): 666-668

Xevi, E., Gilley, J. and Feyen, J. (1996). Comparative study of two crop yield simulation models. Agri. Wat. Man., 30: 155-173. 